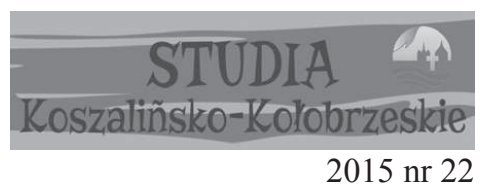

DOI: $10.18276 /$ skk.2015.22-23

Mariusz Rosik

\title{
R. BARTNICKI, K. KŁÓSEK, THE METODS OF NEW TESTAMENT INTERPRETATION. INTRODUCTION, PUBLISHING „PETRUS”, KRAKOW 2014, PP. 291, ISBN 978-83-7720-047-6
}

The Pontifical Biblical Commission in the document The Interpretation of the Bible in the Church (1993) presents methods and approaches for an interpretation of the Holy Scripture. The authors of this document states: "The historical-critical method is the indispensable method for the scientific study of the meaning of ancient texts. Holy Scripture, in as much as it is the 'word of God in human language,' has been composed by human authors in all its various parts and in all the sources that lie behind them. Because of this, its proper understanding not only admits the use of this method but actually requires it" $(\mathrm{A}, 1)$. But even if the historical-critical approach is so important, the members of the Pontifical Biblical Commission are aware that no scientific method for the study of the Bible is fully adequate to comprehend the biblical texts in all their richness. This is why they also present in the document other methods and approaches for the interpretation of the Holy Bible. They pay attention on new methods of literary analyses, especially on narrative analysis.

The publishing house „Petrus” has published recently (Kraków 2014) the book of R. Bartnicki and K. Kłósek, entitled Metody interpretacji Nowego Testamentu. Wprowadzenie (The Methods of the Interpretation of the New Testament. Introduction). The authors decided to present in detailed way two methods of Bible interpretation, still very useful in today's exegesis: historical-critical method and narrative analysis. The book of Bartnicki and Kłósek can be called a handbook; its recipients can be theology students as well as biblical scholars and researchers. R. Bartnicki, the author of the first part of the book, helped himself with three important and quite new books, which were published in German: t. Söding, Wege der Schriftauslegung. Methodenbuch zum Neuen Testament Freiburg im Breisgau 1998), M. Ebner, B. Heininger, Exegese des Neuen Testament. Ein Arbeitsbuch f"'r Lehre und Praxis (Paderborn 2005) and W. Egger, P. Wick, Methodenlehre zum Neuen Testament (Freiburg im Breisgau 2011). For the presentation of the narrative analysis they used mainly English handbooks.

The first part of the book contains thirteen chapters (pp. 9-186) and three annexes (pp. 187-202). R. Bartnicki gives here essential knowledge of biblical criticism and presents also some aspects of history of the described methods and approaches. Presenting Historical Criticism, method that requires a good knowledge of the ancient languages, 
customs, idioms, geography, archaeology, etc., the professor of University of Card. Stefan Wyszyński in Warsaw gives readers a list of lexicons, biblical encyclopedies, dictionaries and introductions to the New Testaments (pp. 17-29). Highly specialized area of research is Textual Criticism. In the chapter dedicated to this area rules of seeking of 'best reading' of biblical text are presented very clearly (pp. 40-56). The chapter VI about Form Criticism (pp. 62-77) is very useful for students who start working on biblical texts. Form Criticism (Formgeschichte) may be defined as historical, literary and theological methodology for analysing 'forms' used in New Testament, especially in the Synoptic Gospels. During the eighteenth century some investigators applied this method to other books of the Bible. In chapter IX the author describes briefly the origin of this kind of methodology and main thesis of its founders and others writers (Bultmann, Dibelius, Zimmermann, Strecker, Berger, Aune, Dormeyer). This part of the book talks also about the reception of this method in biblical sciences until nowadays. Without doubt, Form Criticism remains a central discipline in Synoptic Gospels' and New Testaments' studies. It is still one of the most important methods in the New Testament' investigations, even if it has its own limitations. But in the book of Bartnicki and Kłósek probably it would be better to place the chapter IX (Genre Criticism) just next to the chapter VI, because the presentation of genres (or 'forms') we can find inside the Gospels (parable, miracle story, infancy narrative, passion narrative, apocalyptic saying, wisdom maxims, prophetic saying, anecdotes, legends, etc.) is closely connected to the Form Criticism. In the chapter dedicated to Redaction Criticism (pp. 126-157) a reader can find some practical samples of using this method in individual work on the biblical texts (Matt 9:35; Mk 2:13-22; 6:6b; Lk 8:1-2a; 5:27-39). The annexes in the end of the first part of the book can be very useful for biblical students. We can find here three essays: presentation of the history of Historical Criticism, the list of New Testament' methodologies and principles of preparing bibliography and footnotes in papers concerning biblical studies.

The second part of the book (pp. 203-243), authored by K. Kłósek, is dedicated to Narrative Analysis. This part contains three chapters. In the first one Kłósek presents a communicative model, which embraces such elements as real author, implied author, narrator, narrate, implied reader and real reader. According to Narrative Analysis each narration is composed by two elements: story and discourse. The second chapter presents a story as a factor of each narration. The author pays attention on events, plot, characters, and settings (topographical or geographical, chronological, locative, durative, and typological). In the third chapter the discourse of narration is presented. The discourse is influenced by such elements as the point of view of narrator, rhetoric (repetitions, omissions, irony, symbolism, dialogues and rhetoric figures). Kłósek concludes her study with the statement that Narrative Analysis helps to read New Testament in a life-changing way.

The book Metody interpretacji Nowego Testamentu. Wprowadzenie is intended for Polish language reader, therefore it is very important that along with the presentations of the biblical works of American, German, English, French, Italian and Spanish scholars, Polish names are also present (pp. 20; 23-24; 33-35; 37; 94-96; 113; 156; 177; 179-180; 194). It's a little pity that in working on the first part of the book the author based mainly on German literature, but on the other side we have to admit that German biblical studies on methods of interpretation of the Bible are probably the best from the methodical point of 
view. The language of the entire work is competent, scientific and communicative as well. From an editorial standpoint the work of Bartnicki and Kłósek was prepared carefully. It is featured with the list of abbreviations (p. 6) and footnotes (pp. 245-284). A reader of the book can easily notice that the footnotes for the first part contain discussion on the content of each chapter, but in the footnotes for the second part we have only bibliographical indications.

We can welcome to Polish biblical libraries this excellent book with great joy; the book doesn't omit any of the important issues concerning the modern methods of the interpretation of the New Testament and is really helpful in biblical studies. Polish students and biblical scholars receive a very useful tool for their research and investigations; they receive an excellent compendium of modern knowledge concerning the approaches to the text of the New Testament. 